\section{Nuevas geometrías en viejos paisajes} Cristina Felsenhardt

Las cuestas son un evento típico del paisaje de Chile; en país de cordillera, cerros y valles, este elemento de la geografía ofrece los espectáculos más variados, según en qué zona nos encontremos, ya que los biotopos tienen una expresión muy marcadamente diversa a lo largo de Chile.

La mirada desde lo alto, tan común en Chile, es la que permite las amplias vistas, representadas en tantas pinturas por los maestros; Orrego Luco, Jarpa, los Valenzuela, Strozzi, o Guevara, indicaron ese lujo de la posición del observador sensible de esta geografía; el alto, miradores naturales, desde los cuales se presencia la metamorfosis de los valles, son esos hechos del paisaje que hacen de Chile un país con carácter, un paisaje cordillerano obvio, pero no necesariamente asumido.

Los mantos de extensos viñedos, de textura vinosa y colores cambiantes, cubrieron toda plantación previa; desaparecieron los frutales, los trigos y las hortalizas, dando paso a las vides. $\mathrm{Al}$ desplazarse por el país y debido a la diversidad climática, se van advirtiendo imágenes reconocibles de otras latitudes; quizás la de las viñas sea la más destacable: orden, coherencia paisajística, riqueza y signos de la producción, son las asociaciones naturales que rápidamente impone la razón. Se agolpan recuerdos de paisajes europeos, con el matiz californiano y sus avanzadas tecnologías.

Sin embargo, y casi al mismo tiempo, surgen sensaciones que llenan de sorpresa, y a la vez de afecto por la cosa propia; cercana creación, aparecieron estas realidades productivas que, probablemente sin haberlo previsto, han cambiado tan significativamente el paisaje de este país.

Y digo país, porque "país", "pago", "paisaje", tienen una raíz común y el cambio de paisaje implica también un cambio en el país y en su carácter. Las nuevas viñas han contribuido a una modificación profunda, que va más allá de su propia coherencia vitivinícola; conlleva cambios en las costumbres rurales, en las labores del campo, en su renovada imagen y en su realidad tecnológica.

Era de esperar lo de los valles fértiles, pero lo que llama más la atención del transeúnte es el cambio que han tenido los primeros planos de cerros, que de su secano espinal y geomorfología precordillerana, hoy ostentan una geometría de ortogonalidades superpuestas, líneas que conforman verdaderos cuadros posados sobre la tierra, efecto de la máquina y de la mano del hombre. Las unidades homogéneas de paisaje (UHP en el lenguaje del análisis de paisaje) crecieron en tamaño $y$, en muchos casos, modificaron considerablemente los territorios vistos; la homogeneidad de las viñas ha intervenido en el entorno inmediato y también en los horizontes de los fondos escénicos. El carácter singular de las preexistencias se está transformando hoy en paisajes nuevos. Está cambiando la organización tridimensional del espacio, debido a la expresión de los cultivos nuevos, caracterizados ahora por esta nueva unidad y coherencia, pero sin llegar a la monotonía de los monocultivos, tan perjudiciales para el equilibrio ecológico y paisajístico.

En ese viaje por las carreteras y los caminos de Chile y ahora más fácilmente perceptible, comparece la realidad de los valles transversales que se desarrollan a lo ancho del país, efecto de las aguas y la presencia de la alta cordillera

\section{New geometries in old landscapes}

Cristina Felsenhardt

Hill ridges are a typical feature of Chile's countryside. In this land of mountains, hills and valleys they offer the most varied spectacle, for our long country offers a rich diversity of biotypes.

The view from the heights, so frequent in Chile, provides the sweeping vistas depicted in so many paintings by the masters. Orrego Luco, Jarpa, the Valenzuelas, Strozzi or Guevara reveal themselves as sensitive observers of this geography. The heights, the natural viewing spots from which to watch the metamorphosis of the valleys, these are the events of the landscape which make Chile a country of character, a mountain landscape which is obvious, but not entirely accepted.

The mantle of broad vineyards, wine-textured, changeable in their colors, covers all the previous crops. Orchards, wheat fields, vegetable patches have vanished, yielding to the vines.
As one moves about the country, the climatic diversity throws up images familiar from other latitudes, and the vineyards are perhaps the most noteworthy. Order, landscaped coherence, wealth and the signs of production are the natural associations, which quickly suggest the reason: the memory is flooded with European landscapes, with shades of California and its high technology

But almost simultaneously one is filled with amazement, and with tenderness for what is one's own. The production processes appear. Without meaning to, probably, they have changed this country's countryside most significantly.

Country, I say, for country and countryside have a common root, and the change of countryside means, too, a change in the country and its nature. The new vineyards have helped bring about deep changes that go beyond their winemaking. They have brought changes in rural customs, in the work of the countryside, in its image and its technology.

The fertile valleys were to be expected. But what the traveler most notices is the change in the foreground of the hills. The once dry thorny slopes now display a geometry of superimposed right angles and lines that form squares perched on the land, the product of machines and men's hands. The homogenous landscape units (HLU, in the language of landscape analysis) are larger and often produce major changes in the way the land is seen; and the homogeneity of the vineyards has had an impact on both the immediate surroundings and the horizons. The nature of the old countryside is being transformed into new landscapes. The tridimensional organization of space is changing, thanks to the new crops, which bring their new unity and coherence, without the monotony of monocultures, which so damage the ecological and landscape balance.

In this journey along the highways and byways of Chile the transversal valleys are easier to perceive now. The valleys run the width of the country, the effect of the waters and the high cordillera, which reaches, to the sea. The planted areas nestle in this interrupted geography, benefiting naturally from the surface and underground waters.

Since the beginning of Chile's colonial history, in these same valleys the rural harmony has always been shared with an architectural object. In 
que llega al mar. Las plantadas extensiones se asocian a esa geografía atravesada, aprovechando los beneficios naturales que traen las aguas superficiales y subterráneas.

Justamente en esos valles, ya desde la historia colonial de Chile, la armonía rural fue siempre acompañada por un hecho arquitectónico; antaño, casonas de campo, patios, corredores y tejas, insertos en parques, espacios de privacidades y jerarquía, formaron conjuntos de congruencia total, muestra de refinados gustos de las elites criollas. Las viñas antiguas, de arboledas y parques privados, fueron orgullo de la sociedad rural chilena; hoy aquellos que aún permanecen -y como en la realidad de los palacios europeos- se entregan al público, en su nuevo papel de museos vivientes.

$\mathrm{Si}$ siguiéramos el viaje por estos espacios del tiempo, el ojo todavía puede reconocer símbolos de la campiña chilena, pero ahora con un inesperado cambio de escala; las plantadas colinas a los pies de la cordillera aún rodean las casonas de adobe, pero también sorprende la aparición de volúmenes metálicos, nuevos brillos y colores, edificios industriales de gran tamaño, hitos y altos en los caminos.

En medio de esta nueva realidad de la agricultura chilena se hace presente la búsqueda de formas sintetizadoras de aquella historia pretérita y de la imagen moderna de esta floreciente agroindustria. A lo largo de las carreteras se ha instalado el desarrollo; la arquitectura y el paisaje, unidad inseparable del territorio habitado, son objeto de ese cambio, provocando una nueva sensación de modernidad y bienestar.

En el contexto de la globalización, la introducción y tecnologización de las viñas está asemejando los paisajes a aquellos de otras partes que comparten con Chile el clima mediterráneo; viajar por el sur de Australia, por California, por Sudáfrica o Argentina, se ha convertido en una experiencia similar; la realidad climática ha vestido los territorios de similitudes paisajísticas y a los países de competencias comerciales.

La creciente cultura del vino, la multiplicación de las viñas y la calidad de los climas, al lado de las nuevas arquitecturas de grandes empaquetadoras de frutas, han hecho aparecer también nuevas infraestructuras de apoyo: salas de degustación, restaurantes y hoteles son hoy un nuevo interés para el turismo; la mezcla entre la antigua ruralidad y la expresión de la nueva agroindustria se han convertido en atracción; el parrón se convirtió en estas enormes extensiones de plantaciones tecnologizadas y los

the past the country mansions -the courtyards, corridors and tiled roofs, set in parklands, in their private, hierarchical spaces-formed whollycongruent groupings, a tribute to the refined taste of the local elites. The old vineyards, with their tree-lined avenues and private parks, were the pride of rural Chilean society. Today, those that still remain, like European palaces, are open to the public as living museums.

If we continue our journey through the spaces of time, our eye still recognizes the symbols of the Chilean countryside, but now with an unexpected change of scale. The planted hills at the foot of the cordillera still surround the adobe mansions; but we also catch sight, suddenly, of metal volumes, new color and glitter, huge industrial buildings, halts and milestones on the roads.

In the midst of this new reality of Chilean agriculture there is a search for the forms to pull together the bygone days and the modern image of a flourishing agro-industry. Development has installed itself along the highways, and architecture and landscape, inseparable in populated territory, are being changed, creating a new sense of modernity and well-being.

In a globalized world the new technological vineyards make our countryside look ever more like that of other lands, which share the same Mediterranean climate. A journey through southern Australia, California, South Africa or Argentina offers similar experiences; their climates have given these lands similar landscapes, and their nations similar commercial aptitudes.

The growing wine culture, the multiplication of vineyards and the climate quality, set beside the new architectures of the major fruit packers, has created new complementary structures. Tasting rooms, restaurants and hotels offer new attractions for tourists; the mixture of the old countryside and the new agro-industry has become a draw. The vineyard of old is now a vast technified plantation; the sharecroppers are skilled industrial workers. Old country customs have changed, and in the social landscape there are more bicycles and safety helmets than straw hats and horses. The change is driving rural Chile into the $21^{\text {st }}$ century, a process as clear in its productive countryside as in its presence in world markets.

It is almost a paradox that the novelty of an

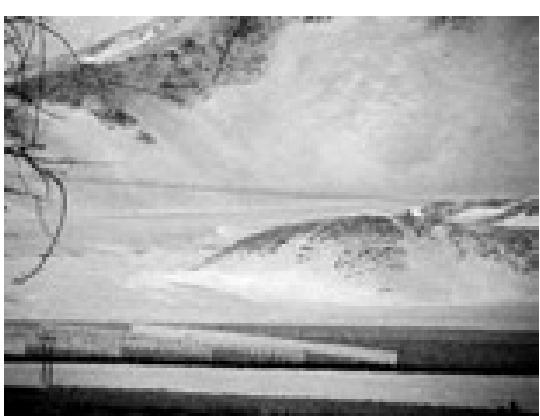

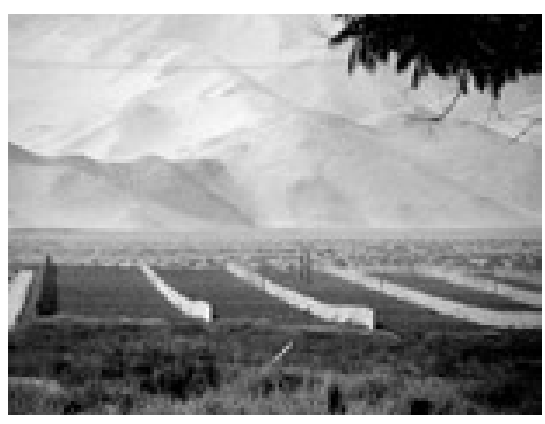
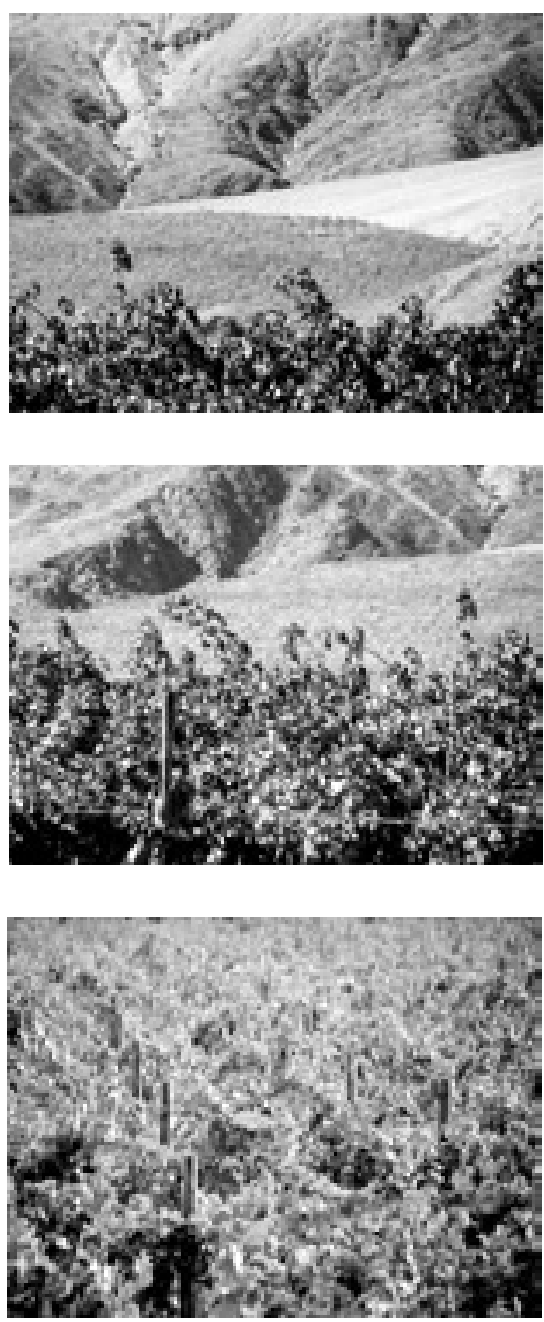

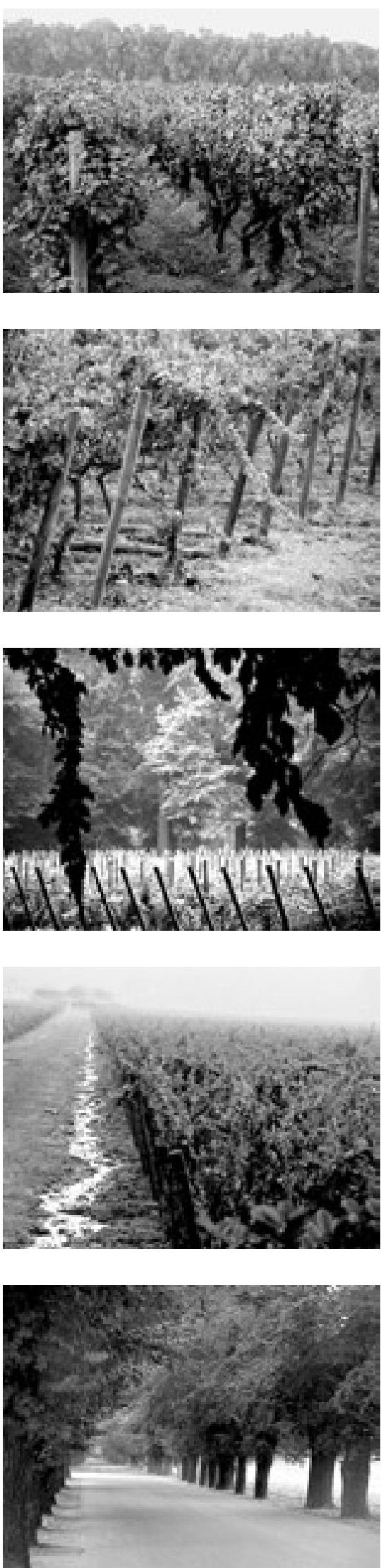

viejos inquilinos de antaño en especializados temporeros industriales. Han cambiado las costumbres del campo y en el paisaje social se divisan más bicicletas y cascos que caballos y chupallas de paja. Chile rural entra en el siglo XXI con fuerza de cambio, notoria tanto en los paisajes de la producción como en la presencia de Chile en los mercados internacionales.

Es casi una paradoja que sea la novedad del campo industrializado la que haya producido un fuerte incremento en el turismo hacia el contexto natural y rural, como una moderna forma de peregrinaje. Esa nueva realidad es la que hoy resulta ser la razón de la revalorización del paisaje como patrimonio; los recursos estéticos, hoy productos vendibles, se han convertido -en Chile tardíamente- en extraordinarios objetos de interés; la apariencia o carácter visible de las zonas bioclimáticas de Chile es todavía un bien gratuito (un lujo paisajístico) en el contexto de un mundo que busca el respiro de la vida urbana, de la excesiva fragmentación del entorno, de la excesiva densidad demográfica y de elementos. En esta verdad nueva la escala de los territorios vastos y las grandes cuencas visuales han atraído a visitantes extranjeros, siempre sensibles a la especificidad y belleza de Chile. Se podría decir

industrialized countryside is drawing tourists increasingly to the natural rural world, like a modern form of pilgrimage. This drive is behind the new appreciation of the countryside as national heritage. Aesthetic resources, now saleable products, have become -if somewhat late in Chile- objects of great interest. The appearance, the visible character of Chile's bioclimatic zones is still a free item (the luxury of landscape) in a world, which seeks relief from urban life, from over-fragmented surroundings, from over-crowding by people and things. In this new reality, the sweeping scale of the countryside and the great river basins has drawn foreign visitors, who always respond to Chile's special beauty. Today it is not the destination but the journey that arouses the greatest interest in travelers; observe the large number of stalls and services on the highways, the sight of entire families driving out of the city to enjoy the beauties of the countryside.

Let us conclude our linking of the vineyards up and down the Central Valley with our perceptions of the countryside by commenting on the three clearly marked sub-zones of the northern regions; the vineyards of the Copiapó que hoy no son las metas de los viajes, sino los trayectos los que suscitan el mayor interés de los paseantes; lo indica la gran cantidad de programas que se han ido instalando en las carreteras; no es raro ver familias enteras saliendo de la ciudad para gozar de las bellezas al paso del vehículo.

Para terminar relacionando las viñas a lo largo del tramo central de Chile con la percepción del paisaje, se podría decir que destacan tres subzonas claramente distinguibles en las regiones nortinas: los viñedos del valle de Copiapó que hoy desbordan sobre el desierto, el valle del Carmen -en el interior de Vallenar-y el valle de Elqui. Los ríos Copiapó, Huasco, y Elqui han permitido que la diferencia se encarne, más aún si observamos los impresionantes cambios que han significado los tranques y embalses; el agua para la producción ha generado nuevos lugares de esparcimiento en sus bordes, comprobándose el hecho de que los seres humanos tienen gran preferencia por los paisajes de agua, sea ésta natural o artificial. Así, el tranque Lautaro al interior del valle de Copiapó, es visitado por turistas, agregándole valor a la zona.

Como ejemplo, en el valle del río Huasco aparece el nuevo lugar de gran interés que se produjo al almacenar sus aguas: los cerros caen formando

valley that now spill over into the desert, the Carmen valley, in the hinterland of Vallenar, and the Elqui valley. The Copiapó, Huasco and Elqui rivers embody the difference, particularly if we look at the extraordinary changes made by reservoirs and dams. Crop watering systems have created new recreation grounds; humans always prefer landscapes with water, whether natural or artificial. The Lautaro reservoir inland from the Copiapó valley is a tourist attraction, bringing added value to the area

In the Huasco river valley an interesting new feature has been produced by the damming of its waters; the surrounding hills have fallen to form a new landscape, which is beginning to be used as a place of rest and enjoyment. The Santa Juana reservoir irrigates the vines in the valley and presents a new tourist attraction. The character of the Elqui valley, queen of the wine countries, has changed drastically with the Puclaro reservoir, which surges up like a gigantic apparition. Reserving our value judgments, we can nevertheless appreciate that the change, made for agricultural reasons, once again has landscape potential. The tourist attraction of the Elqui valley has always been the extraordinary 
un nuevo paisaje, que hoy se empieza a usar como lugar de goce y descanso. El Tranque Santa Juana provee el valle de riego para las vides y al mismo tiempo se constituye en nueva atracción turística. También el valle de Elqui, decano de los paisajes de viñas, hoy cambió totalmente de carácter debido al embalse Puclaro, que surge como gigantesca aparición; sin formular juicios de valor, la modificación, a partir de la necesidad agroindustrial, se convirtió otra vez en un potencial paisajístico. El turismo al valle de Elqui es conocido fundamentalmente por ese increíble contraste entre los secos cerros circundantes y el verdor de las plantaciones, en especial viñedos. Más al sur, en el valle del Limarí, los embalses Recoleta y La Paloma aportan a las plantaciones que suben por los cerros en el área de Monte Patria, generando también un nuevo paisaje de esparcimiento.

En la V y VI regiones las zonas de los valles de Casablanca, Curacaví, Rapel y San Fernando llenan el espacio de viñas, rutas del vino y casonas antiguas visitadas por turistas. Los ríos Cachapoal y Tinguiririca bañan los paisajes y riegan los ricos terrenos convertidos en campo, industria y turismo a la vez, opción ideal como recurso del territorio.
En la VII Región, al interior de Curicó, Talca, San Clemente o Cauquenes, el Mataquito y el gran Maule aportan riqueza a la calidad de suelos y sus viñedos, al mismo tiempo que generan paisajes fluviales de singular belleza; en medio de esos paisajes, compañías transnacionales instaladas en Chile presentan grandes edificaciones industriales, gozando de los bondadosos climas.

La última zona que ha permitido el cultivo de las viñas es la VIII región, donde destaca el microclima de Quillón en el valle del Itata; allí el sol empieza a escasear y los bosques a dominar la escena; es ya el dominio de la flora arbórea, donde la araucaria se yergue en las cumbres y en la sombra se encienden los coloridos copihues.

Como síntesis y a modo de corolario, no existe el mundo simultáneo o universal, igual para todos; cada uno de nosotros construye su mundo propio, nuestro paisaje. La necesidad genética y la inherente necesidad de placer empujan al ser humano a desplazarse en busca de la naturaleza donde solamente a través de la experiencia personal y de la vivencia, se construye nuestro universo y por ende, nuestra identidad.

El paisaje de las viñas ha pasado a ser hoy un elemento que se siente propio y arraigado. ARQ

less generous and the woods are thicker and more dominant; this is the land of trees, where the araucaria stands proud on the mountaintops and the shadows are lightened by the bright copihues.

To sum up: there is no simultaneous, universal world, the same for all of us; we each build our own world, our own landscape. Genetic necessity and the inherent need for pleasure drive the human being to wander in search of nature, where only through personal experience can we build our universe, and our identity.

Today, the vineyards are part of our landscape. They have put down roots. ARQ

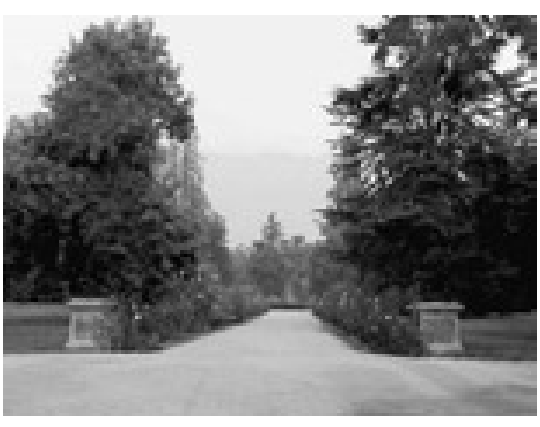

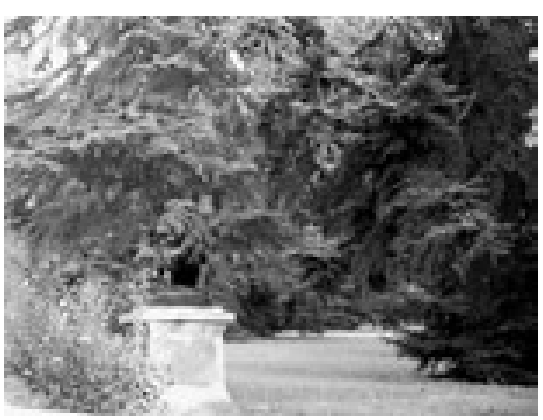
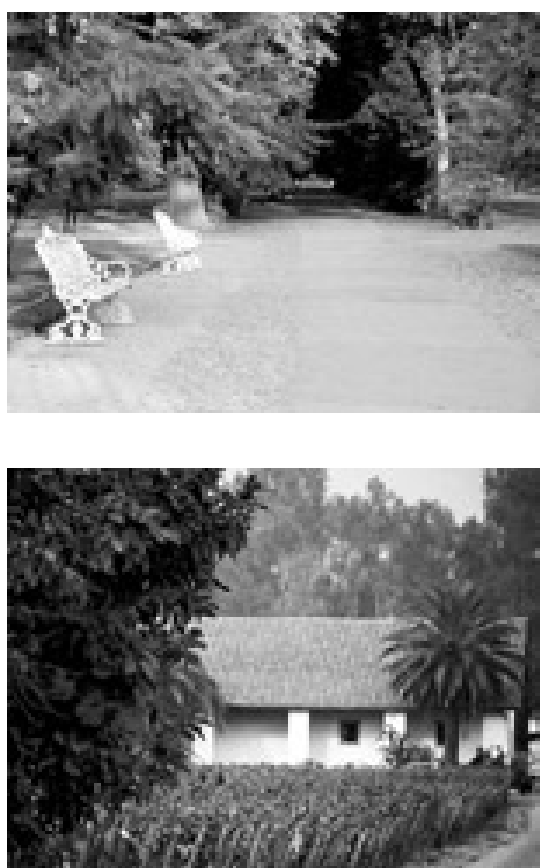
of the resource.

In the VIIth Region, in the hinterland of Curicó, Talca, San Clemente or Cauquenes the Mataquito and the great Maule river bring richness to the soil and the vineyards, along with river landscapes of great beauty. In their midst, transnational companies have set up large industrial buildings, taking advantage of Chile's generous climate.

The last area of wine country is the VIIIth Region, where vines flourish in the microclimate of Quillón in the Itata river valley. The sun is

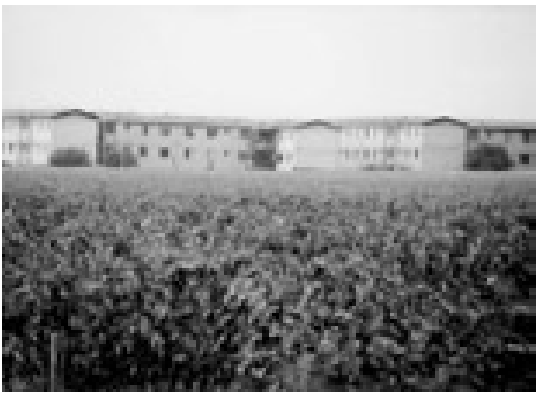




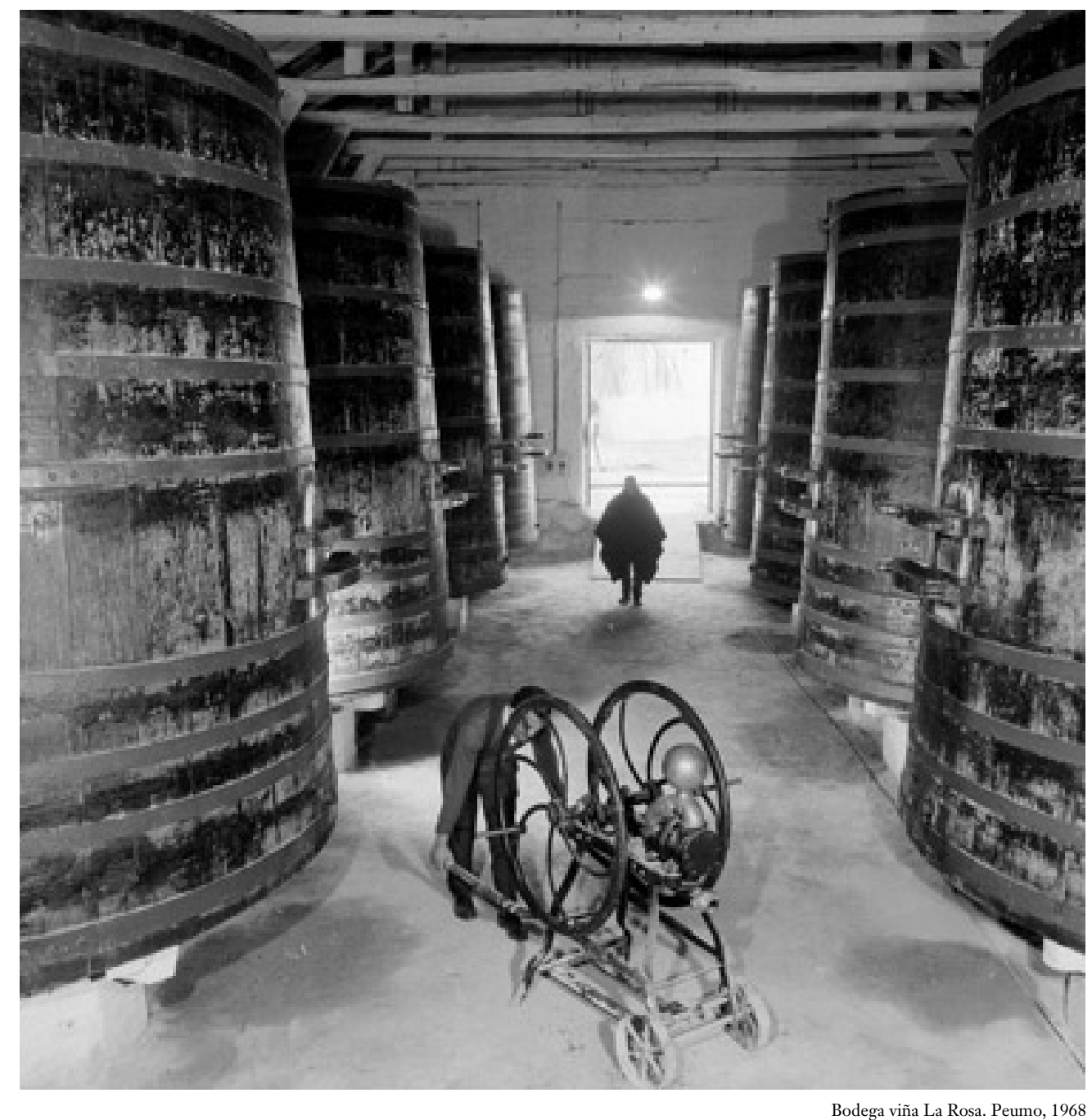

Luis Ladrón de Guevara 